\title{
RABBITS AS A BIOLOGICAL MODEL FOR EXPERIMENTAL STUDIES (review of literature)
}

\author{
O. Tkachuk, T. Tkachuk \\ Ll Medved's Research Centre of Preventive Toxicology, Food and Chemical Safety, \\ Ministry of Health, Ukraine (State Enterprise), Kyiv, Ukraine
}

\begin{abstract}
The Aim of the Research. To analyse and summarize the data of modern literature on the use of rabbits for laboratory experimental studies and substantiate the prospects for their further use.

Materials and Methods. The analytical methods such as collection of scientific information on the problem, analysis of literature data from PubMed libraries as well as scientific generalization of the results obtained were used in the work.

Results and Conclusions. The principles of the prospects for the further use of rabbits for laboratory experimental studies have been substantiated. Thanks to certain scientific advances, ethical alternative scientific testing methods without the involvement of living beings have already been developed and implemented. Exactly these methods help to get more reliable results. If in some scientific research rabbits are no longer used, then in other directions on the contrary, every year the need to use these mammals for experimental studies increases. And there is a well-reasoned explanation for this. Currently, there is no alternative to using rabbits for the production of antibodies, recombinant proteins. Testing in laboratory animals is the best method for detecting phenomena such as cancer and birth defects. Genetically modified rabbits are a new perspective for scientific research. With the development of new technologies, editing the genome, especially CRISPR / Cas9 and its modifications, has made it possible with high efficiency to obtain a much larger number of transgenic animals with precisely specified genetic modifications for solving a wide variety of problems. The use of animals in experiments is critically important for some areas of scientific research because the complexity of the structure of an organism cannot be duplicated in cell culture or using computer models.
\end{abstract}

Key Words: rabbits, maintenance, testing on animals, human health.

Introduction. Research in experimental animals is the most reliable way to identify important toxic properties of chemicals to assess risks to human health and the environment. Why is it necessary to use laboratory animals? People and other living things such as plants, animals, fungi, and bacteria are complex organisms. All living organisms are composed of chemicals, and chemical reactions involve all life processes, which are much more complex than just the sum of individual reactions. When a test substance is introduced into the body of a laboratory animal, it interacts with many organs and tissues. It often happens that by acting on one process, you can cause unexpected reactions in others. Sometimes it is appropriate to divide the research into parts and find out how the injected substance affects each process. The experimenter can detect the various changes that occur when a test substance meets a living cell and draw appropriate scientific conclusions or make specific recommendations.

The Aim of the Research. To analyse and summarize the data of modern literature on the use of rabbits for laboratory experimental studies and substantiate the prospects for their further use.
Materials and Methods. The analytical methods such as collection of scientific information on the problem, analysis of literature data from PubMed libraries as well as scientific generalization of the results obtained were used in the work.

The use of animals in experiments is very important, because the complexity of the structure of a living organism cannot be duplicated in cell culture or using computer models. Thus it is easy to study the metabolic mechanism of the investigated substance, which can change the structure of the substance. "The dose makes the substance poisonous" both at the level of an individual organ and at the level of the organism. But we need to be able to analyse not only how the substance acts, but also the relationship between the dose administered to the animal and the dose delivered to various organs and tissues of the body.

Rabbits are one of the most common laboratory models for research. Rabbits were domesticated in the sixth century, they have been bred for many years, not only for meat and fur, but they are also popular decorative pets. The British Rabbit Council has recognized 76 different breeds of rabbits, but for sci- 
entific purposes the following breeds are mainly used such as New Zealand White rabbit, Californian Giant rabbit, Flemish Giant rabbit as well as American Dutch rabbit.

The New Zealand White rabbit (NZW) is most commonly used in laboratory research. It weighs between $2 \mathrm{~kg}$ and $5 \mathrm{~kg}$ and was bred in the 1920s. This breed is less aggressive in nature and has fewer health problems compared to others. They are small and generally docile, so they are easier to manipulate. They are cheap to maintain, and they reproduce well, moreover they have short life cycles (pregnancy, lactation, and puberty) [6, 19].

Rabbits require a lower temperature for maintenance than most other laboratory mammals. The optimum temperature is between $16^{\circ}-21^{\circ} \mathrm{C}$. The rate of air exchange in the room where the animals are kept is $10-15$ volumes per hour. Recommended daylight hours for rabbits are from 12 to 14 hours. Adult animals should be kept in individual mesh cages $(0,90 \mathrm{x}$ $0,60 \times 0,45 \mathrm{~m})$, located at a height of at least 0.8 $\mathrm{cm}$ from the floor so that excrement can fall into the collecting trays [21].

In vitro, continuous feeding is recommended throughout the day and feed is provided ad libitum, usually in the form of pellets. An adult rabbit's diet can consist of either fresh hay, water, and fresh vegetables, or of ready-to-eat pellets. The water should be changed daily, and it should be available around the clock. Since the body of rabbits is $58 \%$ water, they need to drink at least $120 \mathrm{ml} / \mathrm{kg}$ of water per day. The amount of fluid which is excreted is up to 50$75 \mathrm{ml} / \mathrm{kg}$ daily. Due to the large amount of urine excreted, the collecting trays need to be cleaned frequently (by default, changed twice a week). If water is insufficient, rabbits will consume less feed; after three days without water, they practically stop eating. Signs of dehydration can be detected by looking at the condition of the skin and fur. Rabbits need to be carefully looked after and there should be a daily observation schedule, even on weekends and holidays. This is the standard $[5,10]$.

Newly arrived rabbits are recommended to be quarantined for at least two weeks with daily observation, as well as to be screened for the most common diseases. Rabbits are easily infected with Psoroptes (otodectes mange) caused by the Psoroptes cuniculi mites. The infection can damage the brain, olfactory organ, as well as visual organ. Quarantine also contributes to adaptation to the environment and daily routine in the animal house [7]. In general, rabbits are timid and non-aggressive, they are friends with each other, although males can fight with each other upon reaching maturity. Animals can play with both food and water as well as with equipment, so they need to be monitored to make sure their basic needs are being satisfied. Rabbits are generally easy to work with, but specialists require specialized training. They usually push vigorously with their hind legs when removed from a cage or when a cage is maintained. If they are not held correctly, there is a danger that they can break their spine.

Before carrying out manipulations on animals, it is necessary to make sure that the surface on which the rabbit will be placed for any manipulations or procedures is not slippery: rubber mats are better suited [21]. Daily human contact reduces stress in rabbits during work. It is necessary to wear protective gloves every time. These animals can get nervous and severely bite or scratch with their powerful hind legs. It is not allowed to take rabbits by the ears due to the high probability of dislocation of the cervical vertebrae. They should be taken with one hand by a large fold of skin on the shoulder blades, with the other hand supporting under the hind legs. An experienced technician or researcher will, over time, have an intuitive sense of how to handle rabbits. Some animals instinctively become active in your presence, but when they do not feel that they are being watched, their behaviour may be more obvious to identify problems. Posture should be assessed quickly e.g. slouching indicates discomfort or pain, imperfections in fur can also indicate poor maintenance or lack of it and is often a sign of a sick animal. You should also pay attention to the accumulation of furballs in the stomach. Care should be taken to keep all of bottles with water at about the same level because it could indicate a bottle leak, or a rabbit not drinking properly. Also, an overview of the trays can indicate the amount of urine, as well as faeces in a particular animal. If rabbits are in wire cages rather than on a hard floor, their feet should be regularly examined for hock joint disease (pododermatitis) and their nails should be cut in time [18].

The most famous method of toxicity testing on animals is the Draize Test, developed in 1944 by FDA toxicologists John Draize and 
Jacob Spines. It was first used to test cosmetics. The procedure includes applying $0.5 \mathrm{ml}$ or $0.5 \mathrm{~g}$ of the test substance to the conjunctiva or to the skin of an immobilized animal in consciousness, then washing off the substance after a while and fixing the consequences. Then the animals are observed for 14 days to monitor the signs of tissue damage. The test is usually done on albino rabbits, although other types of animals, including dogs, are used. If the test causes permanent damage to the eyes or skin, the animals are euthanized. If the product does not cause irreversible damage, the animals can be used for the next test [3, 20].

Louis Pasteur used rabbits to develop his rabies vaccine. Medicine did not know any means of combating rabies. It was well known that if a rabid wolf, dog or other sick animal bit, and a person got sick, then there was no salvation, the injured person would die in heavy pain. Pasteur found a way to weaken the rabies virus; he made a vaccine based on a dried spinal cord from a rabbit infected with rabies [17].

For medical products such as vaccines, drugs and medical equipment, rabbits are used to test for pyrogenicity (the ability of a product to cause fever) [8]. Pharmaceuticals are also studied on rabbits, in particular, the irritating effect upon intravaginal administration of the test substance [11].

In addition, due to the high reproduction rate, rabbits are also used to test embryotoxicity and teratogenicity of test substances, finding out the damage that a product can cause to a pregnant female or a developing foetus.

Rabbits are the smallest and cheapest laboratory animal from which serial semen samples can be obtained for morphological and biochemical evaluation as well as for fertility. The female rabbit has an estimated reproductive cycle and can be artificially fertilized with a known amount of sperm during fertility testing. These laboratory animals are extremely valuable models for studying the effects of chemicals or other irritants on the male reproductive system [15]. Rabbits are also used in basic and biomedical research as models for studying diseases of the eyes, skin, heart and immune system, asthma, cystic fibrosis, and diabetes. The literature describes data that, using experiments on rabbits, it became possible to investigate the mechanisms involved in the production of insulin in diabetes [1].
Another common use for rabbits is in the production of polyclonal antibodies, which are widely used for various research and diagnostic purposes [24]. Rabbits are the standard model in periodontal research. Rabbits are also part of various studies, such as measuring the effect of parathyroid hormone on osseointegration in osteoporosis [16]. They have also been used in research on arthrology and tendon healing [9].

Rabbits of the Watanabe breed suffer from fatally high blood cholesterol levels (hypercholesterolemia) due to a genetic defect. These rabbits are being used as a model to improve the treatment of children with this condition and for general research on high cholesterol levels in the body. The mechanisms of plaque dissolution on the arterial walls were also studied in rabbits [25]. Research in rabbits in the nineteenth century played a decisive role in the discovery of the atropinesterase enzyme [13].

Rabbits are an excellent model system for simulating the response of human tissues to radiation from surgical lasers. Modern medicine has many examples of the use of laser technology, in particular, in eye surgery. Undoubtedly, this was preceded by a scientific search, and the models were rabbits. Historically, rabbits have been used to differentiate Mycobacterium tuberculosis from Mycobacterium bovis. When simulating tuberculosis disease, rabbits develop a condition that is similar in features to tuberculosis in humans (granulomas with caseous necrosis). To simulate the action of the human immunodeficiency virus, transgenic rabbits were created in which the human CD4 gene has been expressed [2]. The use of transgenic rabbit models to elucidate the mechanisms involved in disease pathogenesis is a new area of great interest. Transgenic rabbits with altered expression of certain genes were created in 1996 Duverger et al. [4] raised New Zealand White rabbits with human apoA-1 in the liver, in which the effect of increased expression of apoA-1 on the propensity to atherosclerosis was investigated. In recent years, using CRISPR / Cas9 technology, genetically modified rabbits have been used in studies of human diseases from X-linked hypophosphatemia, muscular dystrophy [22] and hypertrophy [14] to retinal degeneration [12] and atherosclerosis [23].

Results and Conclusions. Science has taken a long step forward and has now developed and 
implemented ethical alternative scientific methods of testing without the use of animals that provide more reliable results. When testing cosmetics, instead of testing on rabbits, alternative methods are used, such as studies on cell culture, on artificial skin, as well as tests on volunteers. More than 20 years ago, an alternative Lal test was proposed to determine the presence of pyrogenic impurities in a medicine; until now, rabbits have been widely used for the pyrogenicity test.

But if in some areas of scientific research rabbits are no longer used at all, then in others, on the contrary, every year the number of rabbits used is rapidly increasing. A search for the terms "rabbits" and "experimental model" resulted in 34,837 journal articles published between 1951 and 2020, of which more than 10,000 have been published over the past decade. There is currently no alternative to using rabbits for antibody production. It is the smallest animal that can be used to produce recombinant proteins in its milk or whey, both on an experimental and commercial scale. Testing in laboratory animals is the best method for detecting consequences such as cancer and birth defects.
Genetically modified rabbits offer new perspectives in scientific research. With the development of new technologies for genome editing, especially CRISPR / Cas9 and its modifications, it has become possible with high efficiency to obtain an increasing number of transgenic animals with precisely specified genetic modifications for solving a wide variety of problems. Rabbit genomics and proteomics are advancing rapidly. Many transgenic rabbits have been created that are characterized and available to researchers. Transgenic rabbit models for studying the genetics of specific diseases continue to expand our knowledge of these processes in humans.

Considering the requirements of the bioethics committee (the 3 Rs rule), modern scientists try to use a minimum number of quality standardized laboratory animals in experimental research. The tasks that we must accomplish, the goal that we strive for as scientists is quite ambitious. Therefore, the scientific search that we are conducting cannot be realized only with the help of computer modelling and in vitro methods.
1. Bellón JM, Rodríguez M, Pérez-Köhler B, Pérez-López P, Pascual G. The New Zealand White Rabbit as a model for preclinical studies addressing tissue repair at the level of the abdominal wall. Tissue Eng Part C Methods. 2017;23:863-80.

2. Bosze ZS, Houdebine LM. Application of rabbits in biomedical research: a review. World Rabbit Sci. 2006;14:1-14.

3. Draize JH, Woodard G, Calvery HO. Methods for the study of irritation and toxicity of substances applied topically to the skin and mucous membranes. J. Pharmacol Exp Ther. 1944;82:377-90.

4. Daniel Morton. The Use of Rabbits in Male Reproductive Toxicology. Environmental Health Perspectives. 1988;77:5-9.

5. Duverger N, Kruth H, Emmanuel F, Caillaud JM, Viglietta $\mathrm{C}$, Castro $\mathrm{G}$, et al. Inhibition of atherosclerosis development in cholesterol-fed human apolipoprotein A-1 transgenic rabbits. Circulation. 1996;94:713-17.

6. Fisher PG. Standards of care in the 21 st century: the rabbit. J Exot Pet Med. 2010;19:22-35.

7. Franco NH. Animal experiments in biomedical research: a historical perspective. Animals. 2013;3:238-73.

8. Harkness JE, Wagner JE. The biology and medicine of rabbits and rodents (2nd Ed.). Lea \& Febiger. 1983.

9. Dzherelo dostupu: Thttps://www.toxicology.org/pubs/ docs/air/AIR_Final.pdf

10. Hui JH, Chan SW, Li J, et al. Intra-articular delivery of chondroitin sulfate for the treatment of joint defects in rabbit model. J Mol Histol. 2007;38:483-489.

11. Hunt CE, Harrington DD, Weisbroth SH, Flatt RE, Kraus
AL. Nutrition and nutritional diseases of the rabbit. In: The Biology of the Laboratory Rabbit. New York Academic Press: NY;1974,403-33.

12. Dzherelo dostupu: ISO 10993 - 10: 2002.

13. Kondo M, Sakai T, Komeima K, Kurimoto Y, Ueno S, Nishizawa $Y$, et al. Generation of a transgenic rabbit model of retinal degeneration. Invest. Ophthalmol. Vis. Sci. 2009;50:1371-7. doi: 10.1167/iovs.08-2863

14. Llebenberg SP, Linn JM. Seasonal and sexual influences on rabbit atropinesterase. Lab Anim. 1980;14:297-300.

15. Lv Q, Yuan L, Deng J, Chen M, Wang Y, Zeng J, et al. Efficient generation of myostatin gene mutated rabbit by CRISPR/Cas9. Sci. Rep. 2016;6:25029. doi: 10.1038/srep25029.

16. Oki Y, Doi K, Makihara Y, Kobatake R, Kubo T, Tsuga K. Effects of continual intermittent administration of parathyroid hormone on implant stability in the presence of osteoporosis: an in vivo study using resonance frequency analysis in a rabbit model. J Appl Oral Sci. 2017;25:498-505.

17. Pasteur L. Méthode pour prévenir la rage après morsure. C. R. T. $1885 ; 101: 765-72$.

18. Refinements in rabbit husbandry. SECOND REPORT OF THE BVAAWF/FRAME/RSPCA/UFAW JOINT WORKING GROUP ON REFINEMENT. Laboratory Animals 1993;27:301-29.

19. Sayers I. Approach to preventive health care and welfare in rabbits. In Pract. 2010;32:190-8.

20. Sharpe R. The Draize test-motivations for change. Fd Chem Toxicol 1985;23:139-43.

21. Suckow Mark A, Brammer David W, Rush Howard G, 
Chrisp Clarence E. "Biology and Diseases of Rabbits." Chapter 9 in Laboratory Animal Medicine, 2nd Edition. James G. Fox, et al, editors. New-York: Academic Press; 2002.

22. Sui T, Xu L, Lau YS, Liu D, Liu T, Gao Y, et al. Development of muscular dystrophy in a CRISPR-engineered mutant rabbit model with frame-disrupting ANO5 mutations. Cell Death Dis. 2018;9:609.

23. Wang Y, Niimi M, Nishijima K, Waqar AB, Yu Y, Koike T, et al. Human apolipoprotein A-II protects against diet- induced atherosclerosis in transgenic rabbits. Arterioscler. Thromb. Vasc. Biol. 2013;33:224-31. doi: 10.1161/ATVBAHA. 112.300445

24. Weber J, Peng H, Rader C. From rabbit antibody repertoires to rabbit monoclonal antibodies. Exp. Mol. Med. 2017;49:305. doi: 10.1038/emm.2017.23.

25. Yanni AE. The laboratory rabbit: an animal model of atherosclerosis research. Lab Anim. 2004;38:246-56.

\section{КРОЛІ ЯК БІОЛОГІЧНА МОДЕЛЬ ДЛЯ ЕКСПЕРИМЕНТАЛЬНИХ ДОСЛІДЖЕНЬ (огляд літератури) \\ О.М. Ткачук, Т.В. Ткачук.}

Державне підприємство «Науковий центр превентивної токсикології, харчової та хімічної безпеки імені академіка Л.І. Медведя Міністерства охорони здоров'я України», м. Київ, Україна

PЕЗЮМЕ. Мета роботи. Провести аналіз та узагальнити дані сучасної літератури щодо залучення кролів для лабораторних експериментальних досліджень та обгрунтувати перспектив їхнього подальшого використання.

Матеріали та методи. У роботі застосовані аналітичні методи: збір наукової інформації за проблемою, аналіз літературних даних бібліотек РиbМеd та наукове узагальнення одержаних результатів.

Результати та висновки. Обгрунтовано принципи щодо перспектив подальшого використання кролів для проведення лабораторних експериментальних досліджень. Завдяки певним досягненням науки вже розроблено та впроваджено етичні альтернативні наукові методи тестування без залучення живих істот. Саме вони і допомагають отримати більш достовірні результати. Якщо в деяких наукових дослідженнях кролів вже не використовують, то щодо інших напрямків - навпаки $з$ кожним роком зростає необхідність залучення цих ссавців для експериментів. I цьому є аргументоване пояснення. На даний час немає альтернативи використання кролів для виробництва антитіл, рекомбінантних білків. Тестування на лабораторних тваринах - кращий метод виявлення таких явищ, як рак і вроджені дефекти. Генетично модифіковані кролі це нова перспектива для наукового пошуку. 3 розвитком нових технологій редагування геному, особливо CRISPR/Cas 9 ma його модифікацій, постала можливість з високою ефективністю одержувати набагато більшу кількість трансгенних тварин з точно заданими генетичними модифікаціями для розв'язання найрізноманітніших задач. Використання тварин в експериментах є критично важливим для деяких напрямків наукових досліджень, адже складність будови організму не може бути продубльована в культурі клітин або за допомогою комп'ютерних моделей.

Ключові слова: кролі, утримання, тестування на тваринах, здоров'я людини.

\section{КРОЛИКИ КАК БИОЛОГИЧЕСКАЯ МОДЕЛЬ ДЛЯ ЭКСПЕРИМЕНТАЛЬНЫХ ИССЛЕДОВАНИЙ (обзор литературы) \\ А.Н. Ткачук, Т.В. Ткачук.}

Государственное предприятие «Научный центр превентивной токсикологии, пищевой и химической безопасности имени академика Л.И. Медведя Министерства здравоохранения Украины», г. Киев, Украина

PЕЗЮМЕ. Цель работы. Провести анализ и обобщение данных современной литературы по использованию кроликов для лабораторных экспериментальных исследований и обоснования перспектив их дальнейшего использования.

Материалы и методы. В работе применены аналитические методы: сбор научной информации по проблеме, анализ литературных данных библиотек РивМед и научное обобщение полученных результатов.

Результаты и выводы. Обоснованы принципы относительно перспектив дальнейшего использования кроликов для проведения лабораторных экспериментальных исследований. Наука давно шагнула вперед, и в настоящее время разработаны и внедрены этические альтернативные научные методы тестирования, позволяющие получить более достоверные результаты. В одних направлениях научных исследований кроликов перестали вообще использовать, то в других - наоборот, $c$ каждым годом их использование стремительно увеличивается. В настоящее время нет альтернативы использования кроликов для производства антител, рекомбинантных белков. Тестирование на лабораторных животных - лучший метод выявления таких последствий как рак и врожденные дефекты. Генетически модифицированные кролики - новые перспективы, которые открываются в научных исследованиях. С развитием новых технологий редактирования генома, особенно CRISPR/Cas9 и его модификаций, стало возможным с высокой эффективностью получать все больщее количество трансгенных животных с точно заданными генетическими модификациями для решения самых разнообразных задач. Использование животных в экспериментах является критически важным для некоторых направлений научных исследований, поскольку такая сложность строения организма не может быть продублирована в культуре клеток или с помощью компьютерных моделей.

Ключевые слова: кролики, содержание, тестирование на животных, здоровье человека. 